\author{
Abstracta Iranica \\ Abstracta Iranica Revue bibliographique pour le domaine irano-aryen \\ Volume 32-33 | 2013 \\ Comptes rendus des publications de 2009-2010
}

\title{
Matthijs van den Bos. Elements of Neo-Traditional Sufism in Iran
}

\section{Mauro Valdinoci}

\section{(2) OpenEdition \\ 1 Journals}

\section{Electronic version}

URL: http://journals.openedition.org/abstractairanica/39934

DOI: 10.4000/abstractairanica.39934

ISSN: 1961-960X

\section{Publisher:}

CNRS (UMR 7528 Mondes iraniens et indiens), Éditions de l'IFRI

\section{Printed version}

Date of publication: 1 December 2013

ISSN: 0240-8910

\section{Electronic reference}

Mauro Valdinoci, « Matthijs van den Bos. Elements of Neo-Traditional Sufism in Iran », Abstracta Iranica [Online], Volume 32-33 | 2013, document 370, Online since 01 July 2016, connection on 27 September 2020. URL : http://journals.openedition.org/abstractairanica/39934 ; DOI : https://doi.org/10.4000/ abstractairanica.39934

This text was automatically generated on 27 September 2020.

Tous droits réservés 


\title{
Matthijs van den Bos. Elements of Neo-Traditional Sufism in Iran
}

\author{
Mauro Valdinoci
}

\section{REFERENCES}

Matthijs van den Bos. "Elements of Neo-Traditional Sufism in Iran ", in : Martin Van Bruinessen \& Julia Day Howell, eds., Sufism and the 'Modern' in Islam. London and New York, I. B. Tauris, 2007, p. 61-75.

1 This essay on major developments in Iranian Shiah Sufism in the 20th century discusses the relations between Shiah Sufis and the state, and assesses the impact of sociopolitical changes on the organization of the Sufi orders. Focusing on two particular branches of the Ni‘matullāhiyya, namely the Șafī‘alīšāhī and Sulțān'alīšāhī orders, the author explores Sufi involvement in society and politics throughout the 20th century - in shaping the modern nation-state, from the Constitutional Revolution (1905-1911) through the Reḍā Hāan (r. 1921-1941) and Mohammad Reḍā Pahlavī (r. 1941-1979) eras, and under the Islamic Republic since 1979. According to the author, Shiah Sufism was, during these periods, highly politicized, characterized by ideological and organizational renewal and distinguished by its focus on the nation-state. Conversely, during Khatami's presidency (1997-2005), Shiah Sufism was virtually absent from the public sphere and characterized by another-worldly quietism. Drawing on publications by influential members of the orders studied, the author argues that this quietism did not represent a retreat into a socially disengaged Sufism but, instead, represented a complex engagement with the modern nation-state. This essay is part of the edited volume Sufism and the 'Modern' in Islam (See Abs. Ir. 31, 2008, c.r. $\mathrm{n}^{\circ} 250$ ). 


\section{AUTHORS}

\section{MAURO VALDINOCI}

University of Modena and Reggio Emilia 